\title{
RHEB Gene Rearrangement
}

National Cancer Institute

\section{Source}

National Cancer Institute. RHEB Gene Rearrangement. NCI Thesaurus. Code C153497.

A molecular abnormality indicating rearrangement of the RHEB gene. 